\title{
Impact of Kinetin and Benzyladenine on Growth Performance of Croton in Vitro
}

\author{
Hoda I. M. El-Gedawey ${ }^{1}$, Ali I. H. Abido ${ }^{2}$, Mohamed K. Gaber ${ }^{2}$
}

\begin{abstract}
This study was carried out in the tissue culture laboratory, Faculty of Agric., Saba Basha, Alex. Univ. to fined reliable protocol for in vitro propagation of Croton (Codiaeum variegatun L.) during the period from 2019 to 2020 was developed. Moreover, nodal explants were used during in vitro culture study for indication of multiple shoots and inoculated on various media with different combinations of NAA as auxin and (BA \& KIN) as cytokinin to study compare the effect of the two types of cytokinins on proliferation and development of multiple shoots, and the elongation of the new formed on medium. The best medium for multiplication was a medium supplemented with $2.00 \mathrm{mg} / \mathrm{l} \mathrm{KIN}$ and $(0.50$ or 1.00$) \mathrm{mg} / \mathrm{l}$ NAA. Furthermore, the in vitro shoots showed healthy root development when the tested medium was supplemented with combination of $1.00 \mathrm{mg} / \mathrm{l} \mathrm{KIN}$ and NAA each, in turn. The new formed shoot plantlets (rooted plants) were acclimization ex vitro successfully. The survival rate of the ex vitro grown plants was $95 \%$.
\end{abstract}

Key words: in vitro culture, Codiaeum variegatun L., kinetin, benzyle adenine

\section{INTRODUCTION}

Tissue culture is a propagation technique widely used in modern agriculture because it allows production of many clonal plant from relatively little starting material. Micropropagation is a relatively new technology and application of innovative method that has served to overcome barriers to progress in the multiplication of elite species and further improvments are anticipated (Nasib et al.,2008; Ashish and Sharma, 2011). In-vitro growth and development is considerably influenced by several factors like genotype, age and size of mother plants and explants, the season, growth conditions, media composition, and various other physiological factors (Ashish and Sharma, 2011). Also, as a averages of securing pathogen free plants, culture of shoot apical meristem ideal. Other advantages in the method include rapid multiplications of plants within shorter period of time irrespective of the season (Mulabagal and Tsay, 2004). Keeping the above points in mind was chosen Croton for micropropagation due to its rare success in conventional breeding and also due to

DOI: 10.21608/ASEJAIQJSAE.2020.118280

${ }^{1}$ Agriculture research center, Horticulture Institute, Ministry of Agric., Deprt. of Ornamental and Landscape Gardening, Antoniadis, Alex.

${ }^{2}$ Plant Production Depit., the Faculty of Agric-saba Basha, Alex.univ

Received August 6, 2020, Accepted, September 25, 2020. the meager availability of data for in-vitro production (Shibata et al.,1996; Orlikowska et al.,2000).

An improved and enhanced method was established for the in vitro propagation of croton. Garden croton (Codiaeum variegatum L.) belongs to family Euphorbiaceae that grows naturally in southern Asia, Indonesia, and other eastern pacific islands where it growth in open forests and scrubs. It is an evergreen shrub grown up to usually maintained at 60 to $90 \mathrm{~cm}$ and growth well in areas having humid climate. The family Euphorbiaceae comprises nearly 322genera and 8910species (Bingtao et al.,2008). The family comprises a number of endemic and endangered taxa. Crotons are also well known for their medicinal value. The plant is also well reputed for the production of valuable secondary metabolites of alkaloids, terpens and flavonoids in nature and The leaf extract of crotons antifungal (Maciel et al., 1998; Martins et al.,2002; Puebla et al., 2003).

Croton is an evergreen shrub with alternate, simple leaves mottled with white, yellow or red flowers. The plant may change colour as it matures (Ogunwenmo et al., 2007). Hence, this species has been selected for the different morphology and color combination of leaves with contrasting veins. The leaves are alternate, nonserrated but sometimes lobed. Croton (Codiaeum variegatum, L.) with its amazing colors and leathery leaves is regarded as a beautiful foliage plant commonly known as croton and sometimes called Jopseph`s Coat orvariegated croton (Nasib et al., 2008). Generally, crotons are multiplied vagetatively by cuttings and air layering. These processes are slow in response and require large numbers of mother/stock plants. In spite of its slow rate of conventional multiplication, the plant is very high in demand (Deepa and Shanthi,2013). Hence micropropagation is an alternative average of propagation, to meet its high emergency in relatively shorter time. For instance, from shoot tip cuttings one mother/stock plant can yield only 20 plants per year (Nasib et al., 2008; Mulabagal and Tsay, 2004). Propagation of croton by rooting of soft wood cuttings has been a good development. Some authors have investigated how different compounds of the substrate can improve root induction (Tillmann et al., 1994; Chen 
et al., 2000; Dai-Bisheng, 2007). The present study was aimed to establish an efficient and reliable protocol for in vitro propagation with focusing on rhizeginess of this plant and to compare between the effects of two types of cytokinins on explants grown during (multiplication stage) in vitro.

\section{MATERIAL AND METHODS}

\section{Plant material and explant sterilization}

The plant material was collected from shrubs grown in Antoniadis garden of Ornamental and landscape, research department, Alexandria, Egypt. Plants were sprayed with the fungicide and insecticide 2-3 weeks prior to start initiation Overhead watering was strictly avoided. Freshly grown shoot tips, with two to three nodes, were selected as explants source in August. The collected material was brought to the plant tissue culture laboratory of the Plant Production Department of the Faculty of Agriculture, Saba Basha. Alexandria Unviversity during 2019-2020 seasons and washed, thoroughly, with running tap water for 30 minutes to remove the dust or sand particles.

The shoot tips were cut to nodal segments (single node) as an explants source (Bhattatcharya et al.,1990). The excised explants were dipped in 70\% ethanol for 60 sec. After treatment with ethanol the explants then rinsed with double distilled water twice, so as to lower the toxic effect of ethanol. The nodal segment's surfaces were sterilized using $20 \%$ of sodium hypochlorite for 20 minutes and $1.5 \mathrm{mg} / \mathrm{l} \mathrm{mercuric}$ chloride for $5 \mathrm{~min}$. Few drops of Tween-20, were also, added as a surfactant to sterilized water with sterile gentle shaking under sterile conditions, after 20 minutes the plant material was washed three times with sterilized water and became ready for culture.

\section{Micropropagation}

The explants were cultured on WPM medium (woody plant medium) (Lloyd and McCown,1980) supplemented by different concentrations of cytokinins as benzayel adenine (BA)and kinetin (KIN) at four concentrations:0.0,1.0,2.0 and 3.0mg/l for both each in combinations with the auxin naphthalene acetic acid (NAA) at four concentrations: $0.0,0.25,0.50$ and 1.00 $\mathrm{mg} / \mathrm{l}$.

The explants were cultured in jar containing $30 \mathrm{ml}$ of medium and were placed, vertically. Each treatment was replicated three times and it had three explants (i.e.9 explants/tretement) and incubated in growth chamber at $25 \pm 1^{\circ} \mathrm{c}$ temperature under $16 \mathrm{hr}$ daily light and $8 \mathrm{hr}$ darkness illumination was doue by a florescent light intensity of $2880 \mathrm{lux}\left(40 \mu \mathrm{mol} \mathrm{m} \mathrm{m}^{-2} \mathrm{~S}^{-1} \mathrm{PPF}\right)$. The explants in intiation stage were cultured for 35 days on solidified woody plant medium containing NAA at $1.0 \mathrm{mg} / 1$, only.
This concentration was used based on its success in pervious (photo1).

The newformed propagules from the intiation stage were cultured on to the multiplication medium after sectioned into single leaflets node. The excised nodal cutting explants of the different postitions were cultured onto the WPM medium for 35 days supplemented with cytokinin (BA \& KIN) and auxin (NAA).

\section{Acclimatiztion stage}

The newformed plantlets were then transferred to the greenhouse for hardening. The potting mix used in this study was composed of sand and peat moss (4:1). The transferred plants were monitored weekly for at least 6 weeks.

\section{Statistical analysis}

A completely randomized design was used for all the experiments (Gomez and Gomez,1984). Recorded data were analyzed, statistically, using analysis of variance technique (ANOVA) and averages were compared by the least significant difference (L.S.D.) (Steel et al.,1997) and significance was determined at $\mathrm{p} \leq 0.05$.

\section{RESULTS AND DISCUSSION}

The obtained results of this study reflect its importance to provide more scientific knowledge regarding croton (Codiaeum variegatum $\mathrm{L}$.)

Under the study scope of in vitro plant tissue culture, and they will be presented as follows:

As for data presented in (Table 1) and photo (2) declared that the effectiveness of KIN surpassed its counterpart of BA. The results reveald that all applied growth regulators and their combinations affected highly singinficanthly the studied characters of croton where single nodal explants were grown in vitro for 35 days. However, regarding the average shoot length $(\mathrm{cm})$ /propagule, KIN and BA was in adverse relationship in the given trait; whereas BA and KIN level increased, the studied trait decreased in above level, therefore the $2 \mathrm{mg} / \mathrm{l}$ BA\&KIN gave the highest average value of 2.46 and $4.12 \mathrm{~cm}$, respectively.

Respecting the main effect of BA was the highest average value of shoot length $(2.01$ and $2.46 \mathrm{~cm})$ recorded at $1 \& 2 \mathrm{mg} / \mathrm{lBA}$. While, supporting the culture medium with KIN at all concentrations ( $1 \& 2$ and $3 \mathrm{mg} / \mathrm{l}$ ) gave the highest values $(2.71,4.12$ and $3.41 \mathrm{~cm})$ compared to the other treatments of BA and control.

On the contrary, NAA levels were in proportional relationship, where the levels increased when the highest average values increased, specially at 0.50 and $1.00 \mathrm{mg} / \mathrm{l}$ which gave the highest average values of 3.16 and $3.47 \mathrm{~cm}$ consecutively. 
Moreover, the interaction between cytokinin (KIN) at low concentration $(1.00 \mathrm{mg} / \mathrm{l})$ and high concentration from NAA $(1.00 \mathrm{mg} / \mathrm{l})$ gave the highest average value of shoot length $(6.10 \mathrm{~cm})$.

As for the average number of shoots formed /propagule, the mean effect of KIN showed that augmenting the culture medium whith KIN at $3 \mathrm{mg} / \mathrm{l}$, led to the highest average value (4.42) compared to all other averages. On the other hand, providing the culture medium with either 0.50 or $1.00 \mathrm{mg} / \mathrm{l}$ of NAA resulted in the highest average values of $3.84 \& 3.47$, each in turn.

Furthermore, combination of cytokinin (KIN) and auxin (NAA) at $2,3 \mathrm{mg} / 1$ and $0.50 \mathrm{mg} / \mathrm{l}$, respectively led to the highest averages values (5.93 and 6.14) of number of shoots formed propagule, which expressed, significanitly the highest average value compred to the other treatments.

In this respect, in generally used cytokinin (KIN) gave the highest results in the studied trait compared to using cytokinin (BA) in culture media in this respect KIN or BA levels consider as a favour of stimulation for cell division, morphogenesis (shoot intiation/bud formation) in tissue cultured, and break of apical dominance and release growth of lateral buds ( Raven, 1992; Salispury and Ross,1992; Davies,1995) and their combinations exerted highely significant effects on the multiplication stages characters of croton, where single nodal explants were grown in vitro for 35 days .

With regard to the number of leaflets, cytokinins together with auxin, take part in the regulation of the cell cycle in plant cells (i,e. stimulation of cell division, break apical dominance, enhance axillary shoot proliferation, and adventitious and inhibition root formation. Data showed that $\mathrm{KIN}$ at $3.00 \mathrm{mg} / \mathrm{l}$ gave the highest value (9.35) but BA at $2.00 \mathrm{mg} / \mathrm{l}$ gave (6.83) leaflets/ explant which is the highest value in the BA treatments. Generally, all treatments of KIN gave high values more than the BA treatments. On the other hand, augmenting the WPM with NAA at $1.00 \mathrm{mg} / \mathrm{l}$ gave the highest value (8.65) compared to the other NAA treatments. The interactions between NAA with KIN or BA concentrations showed the highest value with NAA at 0.50 and $1.00 \mathrm{~m} \mathrm{~g} / 1$ and $\mathrm{KIN}$ at $3.00 \mathrm{~m} \mathrm{~g} / 1$, which gave the highest average values (12.23 and 12.03 leaflets/explants, respectively). In general, these results could be brought about to the mod's action of cytokinins on stimulation both cell division and promotion growth of axillary shoots in palnt tissues culture. That, also, found by Tomas (1987), Triginano and Gray (2000) and George et al., (2008). Lemos and Black (1996) showed in Annona muricata that the addition of NAA promoted bud elongation. Nasib et al. (2008) grew the shoot tip explants of Codiaeum variegatum on $\mathrm{MS}+\mathrm{BA}(0.5 \mathrm{mg} / \mathrm{l})+$ pepton $(25 \mathrm{mg} / \mathrm{l})$. and Sana et al., (2012) reported that enhanced shoots and buds proliferation formation can be achieved by using the MS media with $2 \mathrm{mg} / \mathrm{l}$ of both KIN and BA for Codiaeum pictum or $4 \mathrm{mg} / \mathrm{l}$ of both cytokinins. Silva et al., (2013) reported that the longest shoots on croton production being produced on medium supplemented with $1.0 \mathrm{mg} / \mathrm{l} \mathrm{NAA}$, and the combination of NAA and IBA at a ratio of $1: 1 \mathrm{mg} / 1$ of $\mathrm{BA}$ and NAA, respectively led to the production of both number of leaves and longest shoots after a 16 days of subculture period, successfully, especially when cultures were initiated from explants taken from sprouted shoots of corton (Codiaeum vareiegatum, L.). The establishment and multiplication stages were possible when $1 \mathrm{mg} / \mathrm{l} \mathrm{BA}$ was added to the selected cultivar ( Radice, 2010). On the other hand, EL -Shamy et al., (2010) reported that in multiplication stage, adding $5.0 \mathrm{mg} / \mathrm{l} \mathrm{KIN}$ to the culture formed the highest number of shoots of Magnolia grandiflora. While, Chitra and Madhusoodanan (2005) who studid the influence of auxins in direct in vitro and present scenario and future prospects of tissue culture.

This finding could be achieved due to the mode of action of auxin within cultured tissues which may enhance, control various distinctive processes such as cell growth and elongation (George and Sherrington, 1984 and Wilkins, 1989). 
Table 1. Effect of different levels of BA, KIN and NAA (mg/l) and their combinations on the multiplication stage of Codiaeum variegatum $\mathrm{L}$. nodal cuttings cultured in vitro for 35 days

\begin{tabular}{|c|c|c|c|c|c|c|c|c|c|c|c|c|}
\hline \multirow[b]{2}{*}{ Characters } & \multicolumn{2}{|l|}{ NAA } & \multicolumn{3}{|c|}{ KIN levels (mg/l) } & \multicolumn{3}{|c|}{ BA levels (mg/l) } & \multirow{2}{*}{$\begin{array}{c}\text { Mean } \\
\text { NAA }\end{array}$} & \multicolumn{3}{|c|}{ Signification } \\
\hline & $\begin{array}{l}\text { Levels } \\
(\mathrm{mg} / \mathrm{l})\end{array}$ & 0.00 & 1.00 & 2.00 & 3.00 & 1.00 & 2.00 & 3.00 & & NAA & $\begin{array}{c}\text { KIN } \\
\& \\
\text { BA }\end{array}$ & $\begin{array}{c}\text { KINXIBA } \\
\text { XNAA }\end{array}$ \\
\hline \multicolumn{13}{|c|}{ (a)Mean shoot length $(\mathrm{cm}) /$ propagule : } \\
\hline & 0.00 & 1.00 & 1.24 & 1.23 & 2.56 & 1.30 & 1.55 & 1.49 & 1.48 & $* *$ & *** & $* *$ \\
\hline & 0.25 & 1.26 & 2.80 & 3.78 & 3.36 & 1.90 & 2.58 & 2.16 & 2.55 & & & \\
\hline & 0.50 & 2.54 & 3.26 & 5.36 & 3.76 & 2.28 & 2.68 & 2.25 & 3.16 & & & \\
\hline & 1.00 & 3.08 & 3.53 & 6.10 & 3.96 & 2.58 & 3.03 & 2.03 & 3.47 & & & \\
\hline $\begin{array}{l}\text { Mean } \\
\text { (KIN\&BA) }\end{array}$ & & 1.97 & 2.71 & 4.12 & 3.41 & 2.01 & 2.46 & 1.98 & & & & \\
\hline L.S.D. $(0.05)$ & & & & & & & & & & 0.18 & 0.24 & 0.49 \\
\hline \multicolumn{13}{|c|}{ (b) mean number of shoots formed /propagule: } \\
\hline & 0.00 & 0.27 & 1.35 & 2.69 & 2.09 & 1.63 & 2.07 & 2.12 & 1.75 & $* *$ & $* *$ & $* *$ \\
\hline & 0.25 & 0.81 & 2.18 & 3.20 & $4 . .78$ & 2.11 & 2.60 & 2.49 & 2.59 & & & \\
\hline & 0.50 & 0.40 & 2.51 & 5.93 & 6.14 & 3.79 & 3.71 & 3.42 & 3.84 & & & \\
\hline & 1.00 & 0.80 & 3.60 & 4.48 & 4.68 & 3.22 & 3.20 & 3.33 & 3.47 & & & \\
\hline $\begin{array}{l}\text { Mean } \\
\text { (KIN\&BA) }\end{array}$ & & 1.07 & 2.41 & 4.07 & 4.42 & 2.68 & 2.89 & 2.84 & & & & \\
\hline L.S.D.(0.05) & & & & & & & & & & 0.15 & 0.20 & 0.41 \\
\hline \multicolumn{13}{|c|}{ (C) Mean number of leaflets formed/ propagule: } \\
\hline & 0.00 & 2.76 & 5.31 & 5.71 & 6.16 & 4.73 & 5.12 & 5.61 & 5.05 & $* *$ & $* *$ & $* *$ \\
\hline & 0.25 & 3.44 & 4.46 & 6.55 & 6.99 & 5.97 & 6.44 & 8.00 & 5.98 & & & \\
\hline & 0.50 & 6.59 & 8.10 & 7.53 & 12.23 & 6.69 & 7.20 & $6 . .32$ & 7.81 & & & \\
\hline & 1.00 & 6.84 & 9.86 & 10.80 & 12.03 & 6.66 & 8.57 & 5.83 & 8.65 & & & \\
\hline $\begin{array}{l}\text { Mean } \\
\text { (KIN\&BA) }\end{array}$ & & 4.91 & 6.93 & 7.65 & 9.35 & 6.01 & 6.83 & 6.44 & & & & \\
\hline L.S.D.(0.05) & & & & & & & & & & 0.29 & 0.39 & 0.77 \\
\hline
\end{tabular}

L.S.D. $(0.05)=$ Least significant difference teast at 0.05 level of probability*, **: Significant or highly significant.

Mean while, the combination results presented in (Table 2) and photo (3) cleared that applied growth regulators and their combinations affected highly significantly studied characters of multiplication stage number of nodes, number of roots/plant and root length.

However, regarding the average of all characters (number of roots and root length) BA was in adverse relation to the given trait, whereas, BA level increased, the studied trait decreased., therefore the $3 \mathrm{mg} / \mathrm{l} \mathrm{BA}$ gave the lowest average values of all characters.

On the contrary the KIN didn't give the same results but KIN was in advers relationship with number of roots only, but it is more effectively on explants at $3 \mathrm{mg} / \mathrm{l}$ gave the highest number of nodes (7.40) and at $2 \mathrm{mg} / \mathrm{l}$ gave the highest number of roots and root length (5.59 and3.04) each in trun. On the contrary, NAA level where in proportional relationship, were as the levels increased especially at 0.50 or $1.00 \mathrm{mg} / \mathrm{l}$ gave the highest average values consecutively. Meanwhile, the interaction between NAA at 0.50 or $1.00 \mathrm{mg} / \mathrm{l}$ and KIN at 1 or $2 \mathrm{mg} / \mathrm{l}$, recorded the highest average values, with three characters (number of node, number of root and root length) of $8.70,8.45$ and $3.91 \mathrm{~cm}$, each in turn .This result could be explaind by the fact that auxin induced a number of responses which involved cell division, cell enlargement, protein and nucleic acids synthesis which are concomitants of auxin-induced growth and changes in wall plasticity of plant cell and increased apical dominance as there are essential and rapid processes involved in growth and elongation (Wilkins,1989). Our results were further confirmed by the previous findings of Komalavalli and Rao (2000); Sarker and Shaheen (2001); Munshi et al. (2004); Awal et al.(2005);Rajani and Patil(2009); Waseem et al.(2011)who suggested auxin for root induction and development. 
Decreseasing the average values of the studied characters (length of shoot and number of roots) were concomitant with increasing BA in WPM. This finding could be due to accumulation of supra- optimal level of cytokinin within tissues which exerts adverse effects on growth performance (Murashige, 1974; Tomas, 1987; Georg et al., 2008), hence medium without BA resulted in the highest average value of shoot length was taken place. This finding could be attributed to the mode of action of auxin NAA within cultured tissues which is cabable of controlling varius distinctive processes such as cell growth and elongation (George and Sherrington, 1984; George et al ,2008). On the other hand, extreme the lowest concentration of NAA used, affected well the initiation of croton in vitro. This might be owing to that higher concentration of NAA, which is usually ineffective against shoot proliferation (Vijawa et $a l ; 1991$, Waseem et al., 2011). In the resultus were optained by Bakheet, et al., (2018) who reported that the media which containing $1.0 \mathrm{mg} / \mathrm{l} \mathrm{BA}+25 \mathrm{mg}$ peptone (M2) gave highly response for micro propagation followed by in vitro roots were successfully induced by 1.0 or $2.0 \mathrm{mg} / \mathrm{l}$ of IBA which gave the longest and few roots on Codiaeum variegatum (Gold Dust), while $1 \mathrm{mg} / \mathrm{l}$ NAA gave shorter and more root number.

In this respect, in the multiplication stage, the use of KIN not only favoured proliferation of shoots, but also promoted plant height of Croton shoots. Whereas, KIN at $2 \mathrm{mg} / \mathrm{l}$ led to the highest number of shoots and tallest plant, number of leaves., etc . These results could be attributed to the mode of action of KIN which is more effective than BA and /or variation in their metabolism or to active forms or differences in primary mechanism of action as reported earlier. Alternatively, responses of explants to both cytokinins are different due to various aspects. Also, this variation may be due the dgree of cell sensitivity towards both tested cytokinins, which depends on the endogenous level of growth regulators. Likewise, in other occasions, BA was reported to be unsuitable for Croton elongation comperd to KIN in the multiplication stage. The same results were reported by
Biedermann (1987), Luo and Sung (1996) and Kamenika and Takats (1997) on Magnolia grandiflora supported our findings. This later reported result is in harmony with results obtained here, which generally, seems to favour KIN for multiplication stage.

As an explanation for this phenomenon, it is more likely that high levels of KIN utilized in this study (3.00 $\mathrm{mg} / \mathrm{l}$ ) and elsewhere, too, may have caused the removal of apical dominance thus enhancing lateral shoot proliferation (Klimazewska,1981). Also, EL-Shamy (2004) also, reported that Magnolia grandiflora at the multiplication stage, the best medium was WP medium plus the growth regulators KIN (at 5.00 or $6.00 \mathrm{mg} / \mathrm{l}$ ) which increased plant height, number of leaves/shoot and number of shoot. Notably, KIN was better than BA for the multiplication stage of Codiaeum variegatum. Zibbu and Batra (2010) also, found that in vitro leaves of Thevetia cultured on MS medium supplemented with a combination of 2,4-D (2.5 mg/l) and KIN (1or2 mg/l) produced stock callus after 20-28 days of inoculation. Multiple shoots were separated from the cluster and subcultured for their elongation on the same medium along with BAP $(3.0 \mathrm{mg} / \mathrm{l})$. In vitro elongated shoots were rooted on MS medium supplemented with IBA $(0.5 \mathrm{mg} / \mathrm{l})$. Also, Priyanaka et al. (2011) reported that nodal segments of Thevetia peruviana responded with a maximum of $100 \%$ frequency of callus induction on a combination of $9.05 \mu \mathrm{M}(2 \mathrm{ppm}) 2,4-\mathrm{D}$ and $0.93 \mu \mathrm{M}$ $(0.2 \mathrm{ppm}) \mathrm{KIN}$, followed by frequency of $88.3 \%$ on $6.97 \mu \mathrm{M}(1.5 \mathrm{ppm}) \mathrm{KIN}$, supplemented alone. Sana et al. (2012) Found that enhanced shoot and bud proliferation of Codiaeum variegatum can be achieved by using the MS media with $2 \mathrm{mg} / \mathrm{l}$ of both KIN and $\mathrm{BA}$. The in vitro roots were successfully induced with using $5.0 \mathrm{mg} / \mathrm{l}$ of 2,4-D. Nesye et al. (2015) said that the best organogenesis grown internode explants of Thevetia neriifolia response was achieved with a combination of IBA+BA $(0.5+1.0 \mathrm{mg} / \mathrm{l})$. However, better response for maximum shoot proliferation was achieved when BA $(1.0 \mathrm{mg} / \mathrm{l})$ was supplied individually. 
Table 2. Effect of different levels of BA, KIN and NAA (mg/l) and their combinations on the multiplication stage of codiaeum variegatum $L$.. nodal cuttings cultured in vitro for 35 days

\begin{tabular}{|c|c|c|c|c|c|c|c|c|c|c|c|c|}
\hline \multicolumn{3}{|c|}{ NAA } & \multicolumn{3}{|c|}{ KIN levels (mg/l) } & \multicolumn{3}{|c|}{ BA levels (mg/l) } & \multirow{2}{*}{$\begin{array}{r}\text { Mean } \\
\text { NAA }\end{array}$} & \multicolumn{2}{|c|}{ Signification } & \multirow[b]{2}{*}{$\begin{array}{r}\text { KINXBA } \\
\text { XNAA }\end{array}$} \\
\hline Characters & Levels & $\mathbf{0 . 0 0}$ & 1.00 & 2.00 & 3.00 & 1.00 & 2.00 & 3.00 & & NAA & $\begin{array}{c}\text { KIN } \\
\& \\
\text { BA }\end{array}$ & \\
\hline & $\begin{array}{l}(\mathrm{mg} / \mathrm{l} \\
{ }^{2}\end{array}$ & & & & & & & & & & & \\
\hline \multicolumn{13}{|c|}{ (d)Mean number of nodes $(\mathrm{cm}) /$ propagule : } \\
\hline 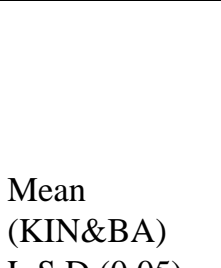 & $\begin{array}{l}0.00 \\
0.25 \\
0.50 \\
1.00\end{array}$ & $\begin{array}{l}1.10 \\
2.16 \\
3.06 \\
3.43 \\
2.44\end{array}$ & $\begin{array}{l}3.12 \\
6.15 \\
6.80 \\
6.63 \\
5.67\end{array}$ & $\begin{array}{l}5.50 \\
5.13 \\
5.63 \\
6.23 \\
5.62\end{array}$ & $\begin{array}{l}5.35 \\
7.26 \\
8.30 \\
8.70 \\
7.40\end{array}$ & $\begin{array}{l}3.30 \\
4.08 \\
5.13 \\
5.33 \\
4.46\end{array}$ & $\begin{array}{l}5.84 \\
5.20 \\
7.13 \\
7.90 \\
6.52\end{array}$ & $\begin{array}{l}2.15 \\
2.66 \\
5.67 \\
5.90 \\
4.09\end{array}$ & $\begin{array}{l}3.76 \\
4.66 \\
5.96 \\
6.30\end{array}$ & $* *$ & $* *$ & $* *$ \\
\hline L.S.D.(0.05) & & & & & & & & & & 0.25 & 0.33 & 0.67 \\
\hline \multicolumn{13}{|c|}{ (e) Mean number of roots formed /propagule: } \\
\hline $\begin{array}{l}\text { Mean } \\
\text { (KIN\&BA) } \\
\text { L.S.D.(0.05) }\end{array}$ & $\begin{array}{l}0.00 \\
0.25 \\
0.50 \\
1.00\end{array}$ & $\begin{array}{l}0.35 \\
2.16 \\
4.67 \\
5.93 \\
3.28\end{array}$ & $\begin{array}{l}0.93 \\
6.13 \\
6.77 \\
8.54 \\
5.59\end{array}$ & $\begin{array}{l}0.43 \\
6.21 \\
7.33 \\
6.13 \\
5.02\end{array}$ & $\begin{array}{l}0.39 \\
6.20 \\
6.44 \\
6.00 \\
4.75\end{array}$ & $\begin{array}{l}1.25 \\
3.19 \\
4.90 \\
6.55 \\
3.97\end{array}$ & $\begin{array}{l}0.66 \\
2.19 \\
3.00 \\
3.33 \\
2.30\end{array}$ & $\begin{array}{l}0.63 \\
1.77 \\
2.20 \\
3.45 \\
2.01\end{array}$ & $\begin{array}{l}0.66 \\
3.98 \\
5.04 \\
5.70\end{array}$ & 0.13 & 0.17 & 0.34 \\
\hline \multicolumn{13}{|c|}{ (f) Mean roots length formed/ propagule: } \\
\hline $\begin{array}{l}\text { Mean }(K I N \& B \\
\text { A) }\end{array}$ & $\begin{array}{l}0.00 \\
0.25 \\
0.50 \\
1.00\end{array}$ & $\begin{array}{l}0.26 \\
1.61 \\
1.77 \\
2.20 \\
1.46\end{array}$ & $\begin{array}{l}1.53 \\
2.13 \\
2.33 \\
2.50 \\
2.12\end{array}$ & $\begin{array}{l}2.30 \\
3.35 \\
3.91 \\
2.60 \\
3.04\end{array}$ & $\begin{array}{l}2.33 \\
3.13 \\
3.65 \\
3.20 \\
3.07\end{array}$ & $\begin{array}{l}1.20 \\
2.11 \\
2.25 \\
2.51 \\
2.02\end{array}$ & $\begin{array}{l}1.38 \\
2.18 \\
2.21 \\
2.30 \\
2.01\end{array}$ & $\begin{array}{l}1.30 \\
2.20 \\
2.18 \\
2.12 \\
1.95\end{array}$ & $\begin{array}{l}1.47 \\
2.38 \\
2.61 \\
2.49\end{array}$ & $* *$ & $* *$ & $* *$ \\
\hline
\end{tabular}

L.S.D. $(0.05)=$ Least significant difference teast at 0.05 level of probability*, $* *$ : Significant or highly significant

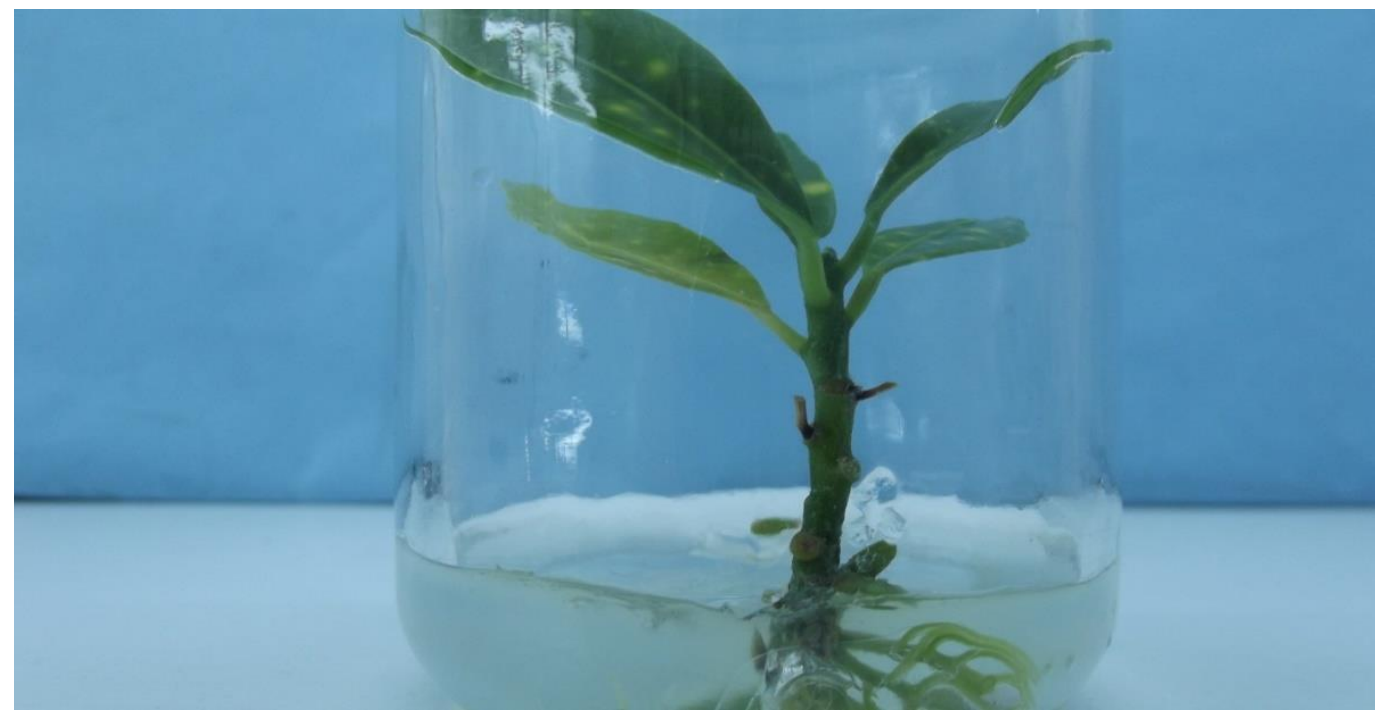

Photo1. initiation stage of croton nodal explants cultured on WPM at 1mg / NAA only 


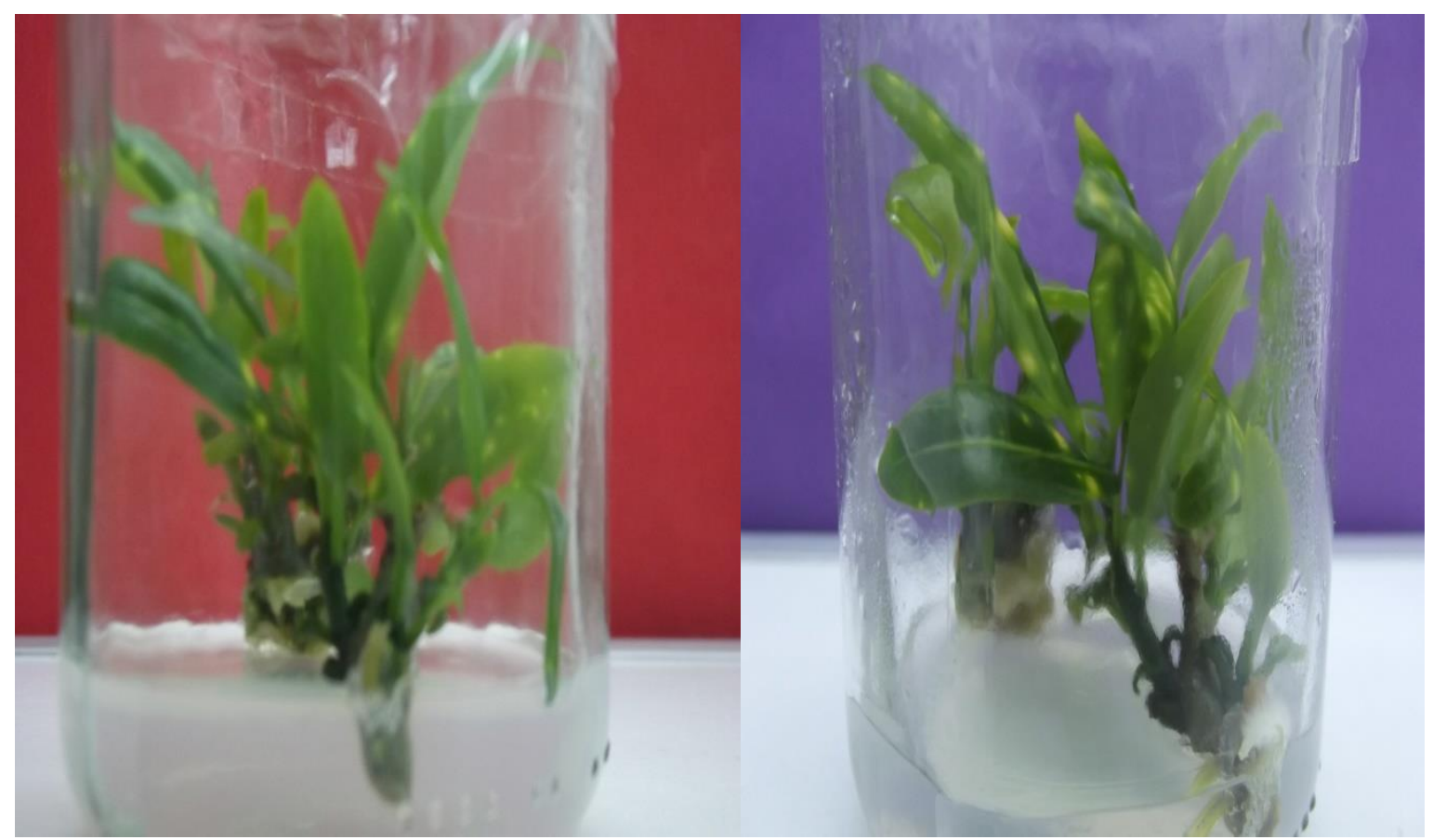

Photo 2. Multiplication stage newlyformed croton shoots of initiation stage culture on WPM $+2.0 \mathrm{mg} / \mathrm{l}$ KIN+1.00mg/l NAA

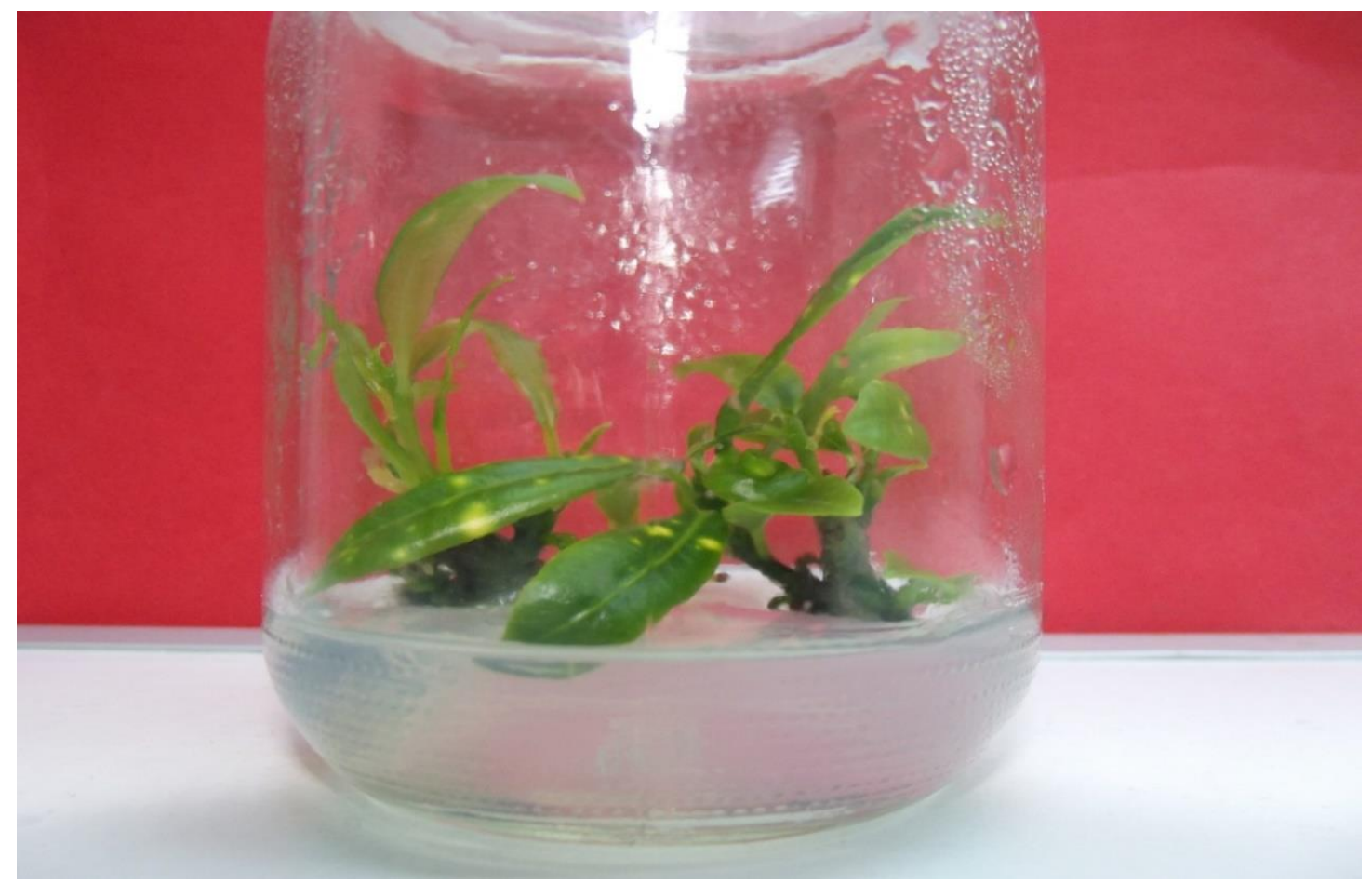

Photo 3. Multiplication stage newlyformed croton shoots of intiatian stage culture on WPM+2.0 mg/l BA+0.50mg/l NAA 


\section{Acclimatization stage}

Acclimatization of in vitro grown plants is an important step in micropropagation (Smart, 2008; Rout et al.,2006). The in vitro grown plantlets with at least two to three roots were transferred to the green house for the acclimatization ex vitro. The potting mix (sand and peat moss,4:1), routinely used in the nursery of our institute, was found sutible for the hardening of the plants The survival rate of the in vitro grown plants treated with KIN in media culture was $95 \%$ as shown in photo (4), while the transaction with BA was $90 \%$.
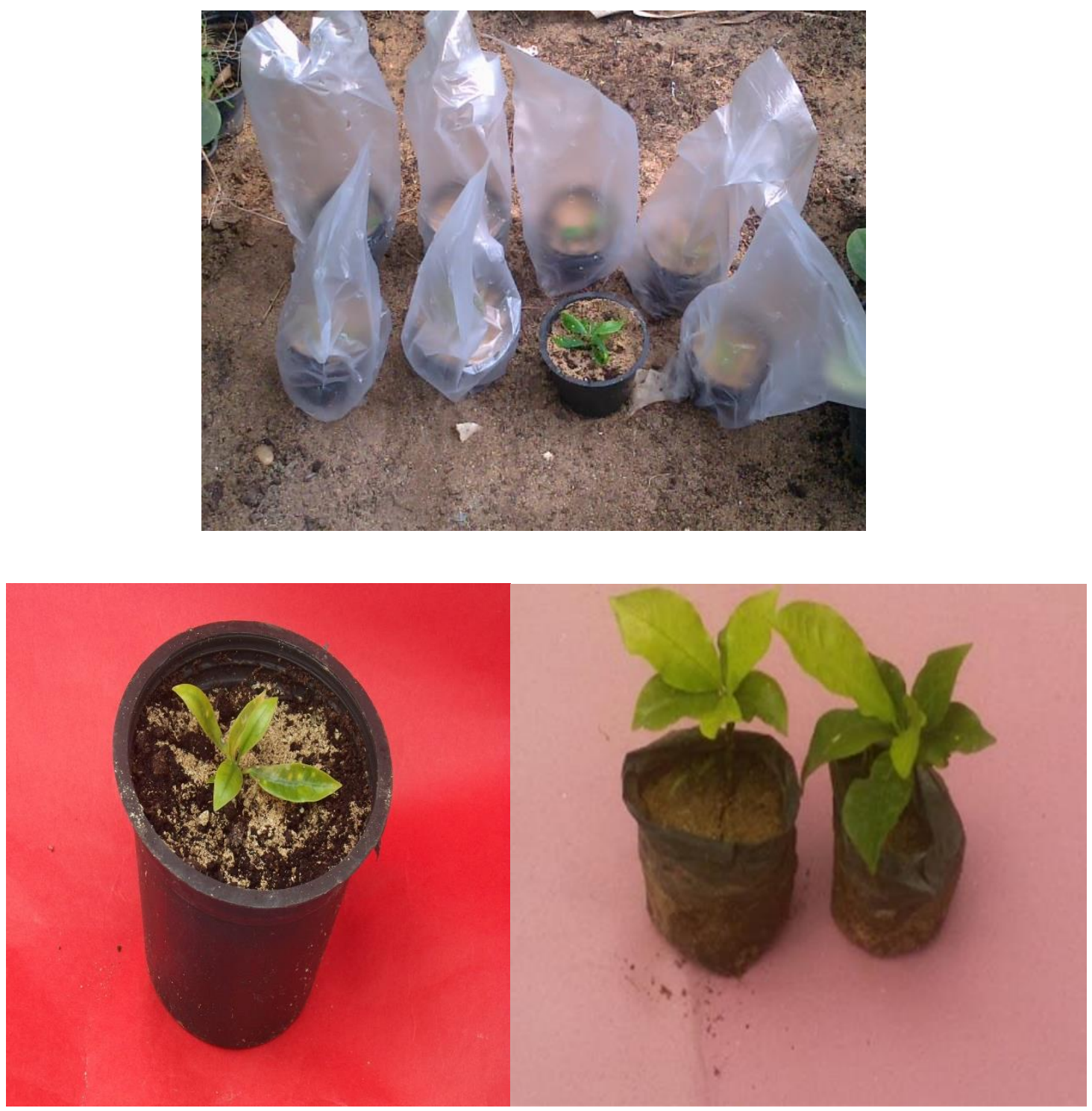

Photo 4. Acclimatized croton tissue culture plants derived from plants ex vitro 


\section{CONCLUSIONS}

It could be concluded that there is a possibility to propagate Croton shrubs by micropropagation. The study here in descried is efficient for the in vitro initiation (rlongation of regeneration shoots), multiplaction shoot proliferation, rooting of nodel segementsof bthis plants. Notably, KIN was better than $\mathrm{BA}$ for the multiplication stage of Codiaeum variegatum in this respect, in the multiplication stage, the use of KIN not only favoured proliferation of shoots, but also promoted plant height of Croton shoots were giving significant effects.

\section{REFERENCES}

Ashish, S. and R.A.Sharma. 2011. Micropropagation of Croton Bonplandium Ball. Inter. Res.J. Pharm (IRJP). 2(10):82-86

Awal, S. M. A., M. R. A. Alam and M. N. U. Hassan. 2005. In vitro propagation of pointed gound (Trichosanthes dioica Roxb.) from shoot tips Biotech. 4(3):221-224.

Bakheet, I. A. G., S. S. Soliman, M. A. I. Abedlkader and M.M.A. ELashtolhy. 2018. Effect of different Croton (Codieaum variegtum L.) Genotypes and growth regulators on callus induction, micropropagation and Antibacterial activities Biotecnology Res. Zagazig J. Agric Res. 45 (1):331-347.

Bhattacharya, P., S. Dev and B.S. Bhattacharya. 1990. Rapid mass propagation of Chysanthemum morifolium by callus derived from stem and leaf explants PL. Cell RFep. 9:439442.

Biedermann, L.E.G. 1987. Factors affecting establishment and development of Magnolia hybrid in vitro. Acta Horti. 212(2): 628-629.

Bingtao, L.I., Q. Huaxing, M.Jin-shuang, Z.Hua, G.Michael, G. Hans-Joachim, E. Stefan Dressler, P. Hoffmann, L.J. Gillespie, M. Vorontsova and G.D. McPherson. 2008. Flora of China.

http://www.efloras.org, dated22ndSeptember.11:163.

Chen, J.J., C. A. Robinson, R.D. Caldwell and D.B. McConnell. 2000. Waste composts as component of container substrates for rooting foliage plant cuttings Proc. Fla. State. Hort. Soc.112:272-274.

Chitra, P. and V. Madhusoodanan. 2005. Influence of auxins in direct in vitro morphogenesis of Euphorbia nivulia, a lectinaceous medicinal plant. In Vitro Cell. Develop. BiolPl. 41:314-319.

Dai-Bisheng. 2007. Effect of carbendazim plus thiram and triadimefon plus ethylicin on the survival rate of three kind softwood cuttings. Huazhong Shifan Daxue Xuebao (Ziran Kexue Ban). 41(1):111-116.

Davies, P.J.N. 1995. Plant Hormones: Physiology, Biochemistry and Molecular Biology. Dordrecht: Kluwer. 833p.
Deepa, D. N. and A. Shanthi. 2013. Propagation crotons from leaves. African J. o Agri. Red. 8(26) :3473-3475.

EL-Shamy, A.A. 2004. Studies on micropropagation of some woody Ornamental PlantsPh.D. Thesis, Fac., Agri., Ain Shams. Univ.

EL-Shamy, M. A., S. S. Ahmed and A. Ibrahim. 2010. Effect of media on propagation of Magnolia grandiflora with tissue culture technique. J. Biol. Chem. Environ. Sci. 5 (4): $277-291$.

George, E.F., M.A. Hall and G.J.D. Klerk. 2008. Plant propagation by tissue culture $3^{\text {rd }}$ Edition. Springer.

George, E.F. and P.D. Sherrington. 1984. Plant Propagation by tissue Culture. Exegeetic Ltd., Basingtoke. U.K.709P.

Gomez, K. and A. A. Gomez. 1984. Statistical procedues for Agricultural Research ( $2^{\text {nd }}$ ed.). An International Rice Researcher Institute Bok. A Wiley Interscience Puplisher. New York.

Http://www.esf.edu/efb/course/EFB530/EFB530Syllabus.htm.

In:Jain, S.M and S.J.Ochatt(eds.,)Protocols for In Vitro Propagation of Ornamental Plants, Methods in Molec. Biol. 589:187-195.

Kamenicka, A. and Takats. 1997. Direct regeneration of Magnolia spp. via in vitro propagation Magnolia, 32(1): 16 (CAB Abstract No. 970309040, 1996).

Klimaszewska, K. 1981. Plant regeneration from petiole segment of some species in tissue culture. Actabotan. 34(1):5-28

Komalacalli, N. and M.V. Roa. 2000. In vitro micropropagation of Gymnemam Slyvestre. Amultipurpose medicinal plant.Pl.Cell,Tiss,Org.Cul. 61:97-105

Kupchan, S.M., I. Uchida, A.R. Branfman, R.C. Dailey and B.Y. Fei. 1976. Antileukemic principles isolated from Euphorbiaceae plants. Sci. 191:571-572.

Lemos, E.P. and J. Black. 1996. Micropropagation of juvenile and mature Annona muricata, L. J. Horti.Sci. Biotech. 71:395-405

Lloyd, G. and B. McCown. 1980. Commercially feasible micro-propagation of mountain laurel, Kalmia latifolia by use of shoot tip culture. Proc. Intl. Pl. Prop. Soc. 30:421427.

Luo, G.F. and W.0. B. Sung. 1996. A brief report on micropropagation of a rare ornamental shrub the red form of Magnolia delavayi. Magnolia. 31 (1):22-27.

Maciel, A.M., A.C. Pinto, S.N. Brabo and M.N. Silva. 1998. Terpenoids from Croton cajura. Phytochem. 49:823-826.

Martins, A.P., L.R. Salgueiro, M.j. Conclaves, R. V., F. Tomi, T. Adzet, A.P. Cunha, S. Canigueral and J. Casanova. 2002. Antimicrobial activity and chemical compostion of bark oil of Croton stellulifer. Planta Medi. 66:647-652.

Mulabagal, V. and H.S. Tsay. 2004. Plant Cell Cultures: An alterative and efficient source for the production of biologically important secondary metabolites. Int. J. of App. Sci. and Eng. 2(1):29-48. 
Munshi, M.K., L. Hakim, M.R. Islam and G. AHMED. 2004. in vitro clonal propagation of Banyan (Ficus benghalensis L.) through axillary bud culture. Int. J. Agric. Biol. 6(2): 321- 323.

Murashige, T. 1974. Plant propagation through tissue culture. Ann. Rev.Plant Physiol. 25:135-166.

Nasib, A., K. Ali and S. Khan. 2008. In vitro propagation of croton (Codiaeum variegatum). Pak. J. Bot. 40(1):99-104.

Nesy, E. A., J. Padikkala and L. Matheew. 2015. In vitro plant regeneration of Theveta neriifolia, Juss from internode explants Via indirect organogenesis.Int J.Pharm Pharm Sci. 7(1):169-172

Ogunwenmo, K.O., O.A. Idowu, C. Innocent, Esan and O.A. Oyelana. 2007. Cultivars of Codiaeum variegatum (L.) Blume (Euphorbiaceae) show variability in phytochemical and cytological characteristics. Afr. J. Biotechnol. 6(20):2400-2405.

Orlikowska, T., Sabata and D. Kucharska. 2000. The effect of leaf and shoot tip removal and explant orientation on adillary shoot proliferation of Codiaeum variegatum Blume va. Pictum Muell. Arg. Cv. Excellent. Sci. Horti. 85(1-2) :103-111.

Priyanaka, S., G. Krian and A.R. Gill. 2011. The influence of plant growth regulators, explants nature and sucrose concentration on in vitro callus growth of Thevetia peruviana Schum. A. J.Bio. 3 (3):280-292.

Puebla, P., J.L. Lopez, M. Guerrero, R. Carron, M.L. Martin, L.S. Roman and A.S. Feliciano. 2003. Neo-clerodane diterpenoids from Croton schiedeanus. Phytochem. 62:551-554.

Radice, S. 2010. Micro-propagation of Codiaeum variegatum (L.) Blume and regeneration induction via Adventitious Buds and Stomatic Embryogenesis.

Rajani, H. and S.S. Patil. 2009. In Vitro response of different explants types on shoot and root development of Ginger. ISHS. Acta Hort.829:VI Inter.Symp. In Vitro Cult. Hort. Breeding.

Raven, P.H., R.F. Evert and S. E. Eichhorn. 1992. Biology of plants. New York: Worth. Pp. 545-572.

Rout, G.R., A. Mohapatra and S. Mohan Jain. 2006. Tissu culture of ornamental pot plant: A critical review on present scenario and future prospects. Biotech. Adv. 24:531-560.

Salisbury, F. B. and C. W. Ross. 1992. Plant Physiology.Belmont,A:Wadsworth. pp. 357-407.

Sana, S., S. Mathew and R.S. Krishnapriya. 2012. Organogenesis and somatic Embryogenesis in various
Cultivars of Codiaeum variegtum (L.) Global Advanced Res. J. Biotec. 1(3):040-047.

Sarker, R. H. and I. Shaheen. 2001. In Vitro propagation of chrysanthemum (Chrysanthemum morifolium Ramat) through callus. Pl. Tiss. Cult. 11(1):85-91.

Shibata, W., Murai, T. Akiyama, M. Siripol, E. Matsunaga and H. Morimot. 1996. Micro-propagation of Croton sublyratus Kurz; a tropical tree of medicinal importance. Plant Cell Rep. 16:147-152.

Silva, B. O. da, A. C. F. Amaral, J. L. B. Ferreira, L. J. M. Santiago and R. B. Louro. 2013. Micropropagation and in vitro production of secondry metabolites of Croton floribundus Spreng. In Vitro Cell. Develop. Biol. Pl. 49(3):366-372.

Smart, S. 2008. EFB530 Plant Physiology, Cytokinins and Cell division, EFB530 plant physiology-Syllabus with lecture notes-spring.

Steel, R. G. D., J. H. Torrie and D. A. Dickie. 1997. Principles and procedures of statistics-a biometric approach. Thired edition. McGraw-Hill Publishing Company. Toronto.

Tillmnaa, M. A. A., C. Cavariani, Z. Piana and K. Minami. 1994. Comparacao enter diversos substrats no enraizamento de estacas de croton (Codiaeum variegtum L.). Sci Agric.51(1):17-20.

Tomas, I. A. 1987. Hormonal regulation of apical dominance.In: P. J. Davis Mortinus Nijoff Publishers.D0rdercht. PP.397-410.

Trigiano, R. N. and D. J. Gray. 2000. Editors, Plant Tissue Culture Conceplts and Laboratory Exericises 2 nd Edition, CRC Prees, Boca Raton. 430 pp.

Vijaya, N., G. Satyanarayana, J. Prakashand and R. L. M. Pierik. 1991. Effect of culture media and growth rgulators on in vitro propagation of rose. Hortic.New Tech. Appl Proce. Inter. Sem.New.Frontiers in Hort., organized by Indo-American Hybrid Seeds, Bangalore, Ind. 25-28,209214.

Waseem, K., M. S. Jelani, M. S, Khan, M. Kiran and G. Khan. 2011. Efficient in vitro argeneration of chrysanthemum (Chrysanthemum morifolium L.) plantlets from nodal segments. Afri.J.Biotechn. 10(8):1477-1484.

Wilkins, M.B. 1989.Advanced plant physiology. The Bath Press, Avon.13-15.

Zibbu, G. and A. Batra. 2010. Eeffect of adinine sulphate on organogenesis via leaf culture in an ornamental plant: Thevetia Peruviana (pers.) Schum. Int. J. Pharm. Sci. 1(2):1-9. 


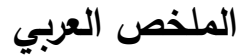

\section{تأثير الكينتين والبنزيل أدنيين على أداء نمو نباتات الكروتن معمليا}

$$
\text { هدى اسماعيل محمد الجداوى، علي إبراهيم علي عبيدو، محمد قدرى عبد الحفيظ جابر }
$$

لتكوين المجاميع الخضريه تحت الظروف المعمليه هى بيئه أكثار النباتات الخشبيه (WPM) المزوده بالسيتوكنيين بتركيز •.ب مليجرام / لتر • بالاضافه الى •0,·ملليجرام /لتر من الاوكسين NAA وكانت افضل بيئه للاستطاله فى بيئه التضاعف هى البيئه المزوده بالاوكسينNAA عند .... ملليجرام /لتر بالاضافه الى السيتوكنيينKIN عند تركيز .. r مليجرام/لتر • وكذلك اظهرت مجاميع جذرية قويه وسليمه عند تزويد البيئه الاوكسينNAA بتركيز ... ملليجرام /لتر . . . أضافه الى السيتوكنيينKIN بتركيز . . . ـ مليجرام

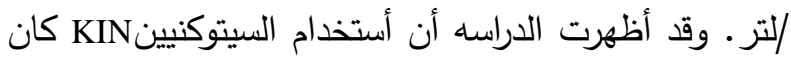
أفضل وأعطى نتائج قويه فى جميع الصفات مقارنه بأستخدام السيتوكنيين BA وكلها معنويه، وقد تم أقلمه جميع النباتات الناتجه معمليا بنجاح حيث تم استخدام خلطه من الرمل والبيتموس (ع : ( ) حيث كانت الافضل فى هذا الصدد.
إجريت هذه الدراسه فى معمل زراعه الأنسجه - قسم الانتاج النباتى -كليه الزراعه سابا باشا- جامعة الأسكندريه

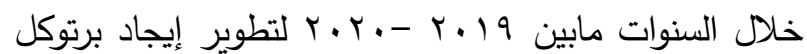
فعال للأكثار المعملى الدقيق لنباتات الكروتن وتقيم تأثير منظمات النمو على أدأ نموه معمليا. ولقد تم أستخدام عقل ساقيه من نباتات الكروتن الناميه بحدائق قسم بحوث الزينه

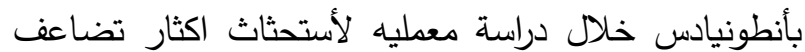

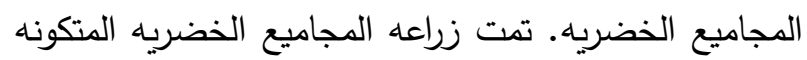
خلال مرحلة البدء او التشين على بيئات مختلفه للتضاعف او الاكثار للحصول على اعداد كبيره متضاعف من تلك المجاميع الخضريه وكذلك لتقيم ومقارنه تاثير منظمات النمو على نمو هذه النباتات معمليا، هذا بالاضافه الى اقلمه تلك النباتات خارج المعمل، بنجاح. وكانت بيئات النمو هى البيئات المضاف لها السيتوكنيين KIN بالمقارنه BA بالاضافه الى تركيزات مختلفه من الاوكسين NAA، وكانت افضل بيئه 